\title{
THE USE OF GIS TECHNOLOGIES IN ANALYZING CHALLENGES AND OPPORTUNITIES FOR THE MANAGEMENT OF URBAN GREEN SPACES IN KIGALI CITY, RWANDA
}

\author{
Rwanyiziri, G. *, Mukanyandwi, M.-C. ** \\ * Dr. Rwanyiziri Gaspard, Senior Lecturer, Centre for Geographic Information Systems and Remote \\ Sensing, University of Rwanda, P.O Box 394 Butare, Rwanda, E-mail: grwanyiziri@nur.ac.rw, Phone: +250788 \\ 681438 \\ ** Mrs. Mukanyandwi Marie Claire (MSc.), Regina Pacis Secondary School of Tumba/Huye District, E- \\ mail: muclaire2001@yahoo.fr, Phone: +250788868833
}

\begin{abstract}
Key words: green spaces, green spaces management, opportunities, challenges, Kigali City, Urban Part of Kigali City
\end{abstract}

This study was assessing the challenges and opportunities for managing Green Spaces (GS) of the Urban Part of Kigali City (UPKC). To find out the GS classes and their threats, the land use classes were identified using GIS technologies. Its output was completed by the field visit, questionnaire survey, informal interviews and desk review of the existing environmental and biodiversity policies and laws.

The land use assessment has shown that the built up areas is the most predominant and occupies $74.3 \%$, while the green spaces occupy only $25.3 \%$ of the total areas of Urban Part of Kigali City (UPKC). Among the GS classes identified in UPKC, wetlands occupy about $62.6 \%$ of the total area of the GS, forests $25 \%$, gardens that are combination of the road side trees, the roundabouts, and playgrounds occupy $12.4 \%$ of the total area of GS while the seasonal and perennial crops areas are not significant in the city. In addition, results have shown that GS play different roles in the city among others, the beautification of the city, the air purification and refreshment, waste water treatment, heat reduction, mind refreshment; act as habitat, food and corridors for a good number of animal, etc.

Even though there is no specific law or policy to the urban GS management and protection, the Government of Rwanda (GoR) has put in place a good number of opportunities that take them into consideration. Those include, (1) the governmental policies such as Environmental Policy, Biodiversity Policy, and Forest Policy; (2) the laws such as Organic Environmental Law and, (3) the plans such the master plans for the three districts that make Kigali City. Despite these opportunities, the management of GS in Kigali City is still facing some challenges that the Kigali City authorities are still trying to address. Those include the lack of policies on GS management, low level of awareness on GS management among local people, and the demographic pressure particularly caused by the rural migration that has led to inappropriate human settlement in some areas of the city, wastes management and pollution.

\section{TIME SERIES ANALYSIS OF GROUND LEVEL OZONE IN KIGALI CITY}

\author{
Beneyo Emmerance Nteziyaremye and Elisée Gashugi \\ University of Rwanda, College of Sciences and Technology, Nyarugenge campus, department of applied \\ chemistry P.O Box 3900, Kigali Rwanda. Corresponding author: nbemmerance@ gmail.com
}

Ground level ozone is a secondary pollutant resulting from photochemical reaction of a variety of natural and anthropogenic precursor mainly volatile organic compounds (VOCs) and oxides of nitrogen (NOx). Under favourable meteorological conditions, ozone may accumulate in the atmosphere and reach a high concentration level that can impose adverse effects on human health and ecosystem.

The overall objective of the study is to evaluate the ground level ozone time series concentrations for three years period (From 18 $8^{\text {th }}$ June 2009 to 6th June 2011) in Rwanda with focus on Kigali city as it has an increasing number of vehicles and many industries which are the major potential sources of ground level ozone sources in Kigali City. 
We have gathered the data from the database air monitoring machine about the ground level ozone concentration located in Kigali at the college of science and technology of University of Rwanda laboratory and the weather information from Rwanda Meteorological Services were used to for the discussion of the ozone data.

The study shows that the weather patterns play an important role in establishing conditions conducive to the ground level ozone formation and accumulation. The air of Kigali city becomes more polluted during the dry season and the concentration of the ground level ozone increases with the temperature.

Comparing the ground level ozone concentration in different season, the results showed that the concentration of ground level ozone was higher in dry season than in the rainy season. This might be related to the wind direction and high wind speed which was observed during the rainy season and low precipitation observed during the dry season.

Keyword: ground level Ozone, time series, seasons.

\title{
IMPACT DE L'URBANISATION SUR LES EMISSIONS DE CO2: ANALYSE EMPIRIQUE POUR LES PAYS D'AFRIQUE SUBSAHARIENNE
}

\author{
Nathan Roger Lea Jombi \\ Département d'économie, Université Laval. Email : Nathanroger2004@yahoo.fr
}

\begin{abstract}
The relationship between urbanization and $\mathrm{CO} 2$ emissions has been the subject of much discussion over the past two decades. Most empirical studies addressed the issue under the environmental Kuznet-curve (EKC) framework and find evidence of an inverted- $\mathrm{U}$ shape path that $\mathrm{CO} 2$ emissions follow as the level of urbanization rises. Yet, more recent studies suggest that the EKC framework may be inadequate, and that the EKC parameter estimates may be dependent on the sample used. The present study contributes to the literature by examining the impact of urbanization on CO2 emissions in sub-Saharan African countries. We use panel data over the period 19702010 and a Stochastic Impacts by Regressions on Population, Affluence and Technology (STIRPAT) model. We find that evidence of the EKC pathway is not robust.
\end{abstract}

Keywords: Urbanization, CO2 emissions, Developing countries, Panel data, STIRPAT model

\section{ИСПОЛЬЗОВАНИЕ КОНЦЕПЦИИ ПЛАСТИКИ РЕЛЬЕФА В РЕШЕНИИ ПРОБЛЕМ СОВРЕМЕННОГО ГРАДОСТРОЕНИЯ}

\author{
И.П. Баранов \\ Федеральное государственное бюджетное учреждение науки Институт биологического \\ приборостроения с опьлтным производством Российской академии наук (ИБП РАН) \\ г. Пушчино, Россия, CEK-MO@rambler.ru
}

\section{USING THE CONCEPT OF PLASTICS RELIEF IN SOLVING PROBLEMS MODERN CITY PLANNING AND ARCHITECTURAL PLANNING}

\author{
I.P. Baranov \\ Federal State Institution of Science Institute of Biological Engineering with Pilot Production of the \\ Russian Academy of Sciences (RAS UPS) \\ Pushchino,Russia,CEK-MO@rambler.ru
}

\begin{abstract}
This paper describes the application of the concept of the method of plastic relief in solving problems of urban planning and architectural planning as an example of Pushchino and Moscow.

Введение. В современном градостроительстве возникает немало проблем: с перепланировкой, ремонтом аварийных объектов, сносом, выбором площадки для строительства в условиях плотной застройки
\end{abstract}

